\title{
Ecology and Biological Resources of Melliferous Plants in the Vasyugan Plain and their Importance for the Arctic Belt
}

\author{
Vladimir Kashkovsky, Alevtina Plakhova, Irina Moruzi, Vladimir Tokarev, Dimitry Kropachev \\ ${ }^{1}$ Novosibirsk State Agrarian University, 160 Dobrolyubov Street, Novosibirsk, 630039
}

\begin{abstract}
Searching for mineral and energy resources in various regions of the Arctic basin has revealed the presence of huge reserves of oil, gas and other extractable resources. The coast of the Arctic Ocean, i.e. the European and the Asian north of Russia turns into the region of active economic development.

Population migration flows into these regions will increase every year. People will move from the favorable climatic conditions to the extreme conditions of the Arctic. The harsh conditions of the Arctic are particularly heavy for the weather sensitive people with increased excitability of the central nervous system.

In the extreme weather conditions, food is the most important means of organism protection. Therefore, a balanced diet is the most important means of human adaptation in the northern latitudes, with bee-farming products playing a huge role $[4,7]$.

The Great Vasyugan swamp is the largest swamp with the area of 53,000 km². It covers the Ob-and-Irtysh watershed, and stretches within $55040^{\prime}-58060^{\prime} \mathrm{N}$ and $75030^{\prime}-83030^{\prime} \mathrm{E}$; its southern border stretches $573 \mathrm{~km}$ from the right bank of the Irtysh River to the left bank of the Ob River. From the southern border to the north, the swamp stretches for $320 \mathrm{~km}$. In this area, there are huge reserves of peat, which make over $61 \%$ of the total stock in Russia. Among the swamp, there are islands, i.e. spaces not occupied by swamps and lakes, and covered with forest and grass [2].

In the Tsarist times, the Vasyugan swamp was considered unsuitable for agriculture. Development of this region started after the October revolution. People grew gray cereals, fodder crops, potatoes, and vegetables. In this area, local horse breed named "narymka" was bred. After the Great Patriotic war, the Vasyugan Plain, or the Narym territory was deserted. Settlements were removed, and bushes and grass started growing in their place.

Currently, the Great state program for studying the Narym territory has been started for using these areas to grow agricultural products to be supplied to the population of the Arctic Belt.
\end{abstract}

Keywords: Vasyugan Plain, ecological beekeeping, organic honey, swamp, Narym, beekeeping, bees' appearance in Siberia, fodder herbs, meat horse breeding, fattening.

\section{Introduction}

Geographically, the Vasyugan swamp is almost evenly located on both sides from the border between the Novosibirsk and Tomsk regions, and stretches very little to the northwest in the territory of the Omsk region. The share of the Novosibirsk region is the territory of about 1.6 million hectares.

The area is characterized by harsh climatic and natural conditions. The winter comes early, followed by late spring with continuous colds. Numerous swamps are located throughout the entire territory. The entire territory of 573 kilometers between the Irtysh and the $\mathrm{Ob}$ rivers gets covered with water during the flooding period. This creates a huge sea with water and forest.

After the water recesses, gray cereals and fodder herbs may be cultivated in the dry places between the swarms. Cereals might be cocksfoot, awnless brome; genera: foxtail, slough grass. Legumes are sweet clover, white sweet clover, white trefoil, rose trefoil, red clover, and blue alfalfa. These herbs can provide good diet for milk and meat capital, and for fattening in meat horse breeding. In this area, a valuable local breed of horses named "narymka" has been bred. In addition to cattle breeding and horse breeding, the wealth of the Vasyugan Plain can be efficiently used by the beekeeping industry.
In the vast territory from the Urals to the Pacific coast, there were no Apis mellifera L. honeybees [1, 8, 9, 11, 12]. Appearance of honeybees in the Western Siberia is associated with human activity. The first attempt was taken by Major-General Scalona. At his order, 30 bee trees were imported from Bashkiria in the winter of 1776/77. The imported bees were distributed among inhabitants of the Western Altai in villages Bobrovka and Sekisovka of the Tomsk province. In the spring and summer of 1778, families had 3 and more swarms. The people who got these bees behaved greedily, and took almost all the honey. Very little honey was left for the winter, and all bee families died of starvation.

The second attempt to import bees into Siberia was taken at the order of colonel N.F. Arshenevsky - the commandant of the UstKamenogorsk fortress. Honey bees Apis mellifera L. of the central Russian breed $[11,12]$ were imported from the Urals, and thus he became the founder of the Siberian beekeeping.

With the help of this man, bees started quickly spreading from Western Altai to Western and Eastern Siberia. In 1825, 4.5 bee families accounted to each inhabitant of Western Siberia, and honey became cheaper than sugar $[3,5,7,8,9]$.

All beeyards were created to the limit of $50^{\circ} \mathrm{N}$. Beeyards were not created above $50^{\circ} \mathrm{N}$, and no works were done in other branches of agriculture. 
Currently, the problem exists in developing beekeeping in the territories located $320 \mathrm{~km}$ to the north from $50^{\circ} \mathrm{N}$. The difficulty in solving this problem is the absence of state support for the industry.

The research was performed between 1987 and 2018.

The research was aimed at assessing the Vasyugan swamp for using it for beekeeping, cattle and horse breeding.

The problem required resolving the following tasks:

1. Ecological assessment of the Vasyugan Plain, and the possibility of creating Organic Beekeeping and obtaining Organic Honey.

2. Determining the availability of melliferous and ambrosiacarrying plants' growing in the Vasyugan Plain, and identifying the most productive plants in the harsh climatic conditions.

3. Determining the influence of the ecologically safe area and natural vegetation on the development of bees' competitors.

4. Determining the abilities of the fodder base for production of inexpensive ecologically safe horse and beef meat.

5. Determining the fodder for developing meat horse and cattle breeding with natural fattening.

\section{Methods}

For resolving these tasks, the following research methods were used:

1) Environmental safety was assessed by the wind rose, by visual inspection of the territory, by detecting enterprises and other anthropogenic influences that polluted the area and created environmental hazards.

2) Availability of melliferous and ambrosia-carrying plants was determined by multiple fixed-route passages. During the fixed route inspections, the availability of herbaceous, shrubby and forest vegetation suitable for nectar and pollen collection, and fodder crops for feeding agricultural animals was determined.

3) The environmentally safe area in the harsh climatic conditions was studied for suitability for beekeeping by the availability of the most sensitive species and families of insects, their numbers, and ways of feeding. Entomological literature describes a well-known method of determining the number of insect species in a particular area. However, this method did not give the answer to the question of how and where the insects fed. Therefore, the authors developed a method for determining the number of insects and their interaction with the plants, what plants competitors of bees collect nectar and pollen from. This was simultaneously determined by 60 persons on 60 plant species within the entire light day; the insects were counted for 3 days.

Inspections were performed on vehicles, on horses, walking and via satellites; they helped establish that in the area of the Vasyugan Plain or the Narym territory, there were no industrial facilities that could pollute the atmosphere, the soil, water bodies, and vegetation. It has been found that there were no highways or motorways that could pollute the atmosphere. After that, the availability of rural settlements and their activity was determined: cattle breeding, cultivation of feral, technical, and other agricultural crops, as well as the way the heavy farm equipment was used: tractors, harvesters, sewing machines, and hey making machinery. Pastures and their use had been evaluated. In addition to these studies, the wind rose was determined. The wind rose and the performed visual assessments of the area had shown that there were no environment pollutants in the entire area of the Vasyugan Plain.

Environmental safety in the area was assessed experimentally; for this purpose, the living conditions of various insect species were determined. Insects are very sensitive to purity of the atmosphere, and to pollution of soil, water, and plants. For this purpose, two indicators that can be easily accessed were taken - the number and the species composition of insects.

\section{Results}

The southern part of the studied area, where the climatic conditions are more favorable for life, is more subjected to the strong anthropogenic influence of the population of large cities. People move in vehicles, cultivate fields with machinery, use insecticides and pesticides. In urbanized areas, there are almost no biting insects, and most important, only three species of bumblebees have been discovered.

In the northern zone $-150 \mathrm{~km}$ to the north, despite the harsh climatic conditions, blood sucking insects are present in abundance, along with 12 species of bumblebees.

Indicators of eco-coenosis purity are the main plant pollinators: bumblebees (Bombidae) and mellifluous bees (Apis mellifera L.). According to the laws of coevolution, they cannot live without plants, and plants cannot reproduce without them. Using these indicators, parallel calculation of the number of bumblebees in the area of human activities was performed $(50 \mathrm{~km}$ to the South from $50^{\circ} \mathrm{N}$ ) and $100 \mathrm{~km}$ to the North from $50^{\circ} \mathrm{N}$.

Table 1: The number of insects pollinating flowers of plants per $1 \mathrm{~m}^{2}$ within 1 hour in the morning, in the afternoon, and in the evening (the beeyard in the northern area of the Novosibirsk region)

\begin{tabular}{|l|c|}
\hline \multicolumn{1}{|c|}{ Indicators } & $X \pm S_{\bar{X}}$ \\
\hline \multicolumn{2}{|c|}{$9.00-10.00$} \\
\hline Apis mellifera L. & $11.6 \pm 1.96$ \\
\hline Bumblebees (Bombidae) & $3.7 \pm 1.06$ \\
\hline Muscid flies (Muscidae) & $7.7 \pm 0.97$ \\
\hline Social wasps (Vespidae) & $3.5 \pm 0.73$ \\
\hline Other insects & $5.2 \pm 0.76$ \\
\hline \multicolumn{2}{|c|}{$12.00-13.00$} \\
\hline Apis mellifera L. & $12.6 \pm 2.0$ \\
\hline Bumblebees (Bombidae) & $4.0 \pm 0.45$ \\
\hline Muscid flies (Muscidae) & $4.2 \pm 0.38$ \\
\hline Social wasps (Vespidae) & $2.5 \pm 0.47$ \\
\hline Other insects & $4.2 \pm 0.71$ \\
\hline \multicolumn{2}{|c|}{$17.00-18.00$} \\
\hline Apis mellifera L. & $6.6 \pm 1.18$ \\
\hline Bumblebees (Bombidae) & $2.5 \pm 0.61$ \\
\hline Muscid flies (Muscidae) & $2.9 \pm 0.46$ \\
\hline Social wasps (Vespidae) & $1.3 \pm 0.27$ \\
\hline Other insects & $3.3 \pm 0.65$ \\
\hline
\end{tabular}

The number of insects was studied at various times of the day. The research has shown that in the area of the Vasyugan swamp bees and bumblebees were active within the entire day. They were especially active at midday (12.00 to 13.00). At the end of the day, bees and bumblebees continued gathering nectar. This can be explained by their biology. Bees and bumblebees collect nectar and pollen both for themselves, and for the family as a whole, as well as for creating reserves without which the family will not survive the winter. They have to satisfy the need of the entire family, therefore, they work all day long. In the morning, there are fewer of them on flowers than at midday. This happens because at midday, air temperature is the highest, which contributes to secretion of nectar and pollen, thus being the most suitable time for collecting nectar. A foraging bee and a foraging bumblebee collect nectar and pollen all day long, while there is the physical possibility of working actively, since they collect nectar and pollen both for feeding the bee family, and for preparing the stock.

Other insects behave differently. Male and female flies feed on the nectar. They visit flowers to satisfy their own need in food. If they become bellyful in the morning, they do not have the need to visit flowers during the day. Flies use the warmest part of the day for reproduction: laying eggs, mating, muscle training, searching for good locations for egg-laying, where the offspring will not be attacked by native animals (insects or birds).

The family of social wasps in Siberia has about 470 species [10]. Wasps of all species live in temporary families like bumblebees, but this is the only similarity. They are very different in the way they feed. Bumblebees are vegetarians, they feed on pollen, there- 
fore, every bumblebee feeds itself and brings feed to the nest for feeding the larvae and young bumblebees; in addition, it is necessary to create the stock for feeding the family in adverse conditions. Bumblebees are forced to collect nectar and pollen every day. Adult wasps are also vegetarians, but their larvae are predators. Adult wasps collect nectar only for satisfying hunger. Wasp families in a nest do not need nectar at all, and therefore, they do not store it. During the warmest period of the day from 12:00 until the evening, wasps catch gad-flies, mosquitoes, butterflies, flies and other insects, which are the most numerous at this time. Wasps take the caught gadflies, spiders, flies, and other insects to the nest, where they munch them and feed larvae. The largest wasp - giant hornet (Vespa crabro L.) catches drones and working bees, and feeds them to its larvae [6].

Lepidopterous males do not live long; they live until mating with a female, and die afterwards. They do not need nectar, the stock of nutrients accumulated during development is sufficient for them. It is only females that feed on nectar.

Among blood-sucking insects, these are males who feed on the nectar. Nectar is an energy food, and they need it for being active finding females and mating with them. Females do not feed on nectar, they search for highly nutritive product - blood of animals, therefore, they search for a place where they can drink blood to satiety.

Wasps, flies and other insects are active and feed hard in the morning; at midday, the flower visiting rate decreases almost by $50 \%$, and decreases further towards the evening. Such difference is explained by the fact that bees and bumblebees collect nectar and pollen, while the rest of insects simply satisfy hunger. This explains the fact that in the morning the insects are bellyful, by the midday they are partly hungry, and there are still fewer hungry ones by the evening.

Observations of the wind rose and human activities in the area of the Vasyugan swamps, as well as direct observations of insects' activity and the number of them on the flowers have shown that the area of the Vasyugan Plain is an ecologically safe area with a large army of competitors to honeybees. This army of competitors actively collects nectar and pollen during the entire light day. No nighttime competitors were detected in the area of the Vasyugan Plain; it is believed that they do not withstand the night colds of the Vasyugan Plain.

These results were obtained in the eastern part of the Vasyugan swamp. To finally understand the issue about honeybees' competitors, similar researches were made in the central part of the Vasyugan swamp. This part differs from the eastern one in the increased number of growing plant species that produce nectar and pollen. The same species were detected, and many new ones were found. The total of 144 plant species were found. All 144 species of plants produced nectar, and attracted all insects that fed on them. Out of this number, the authors identified 44 species that occupied large areas, and were most intensively visited by insects. Three times a day for one hour, all insects that sucked nectar from honey cups and collected pollen from stamens were counted (Table 2).

Table 2: Determination of the number of honeybees' competitors in the central part of the Vasyugan Plain, $n=44$

\begin{tabular}{|c|c|c|c|c|c|}
\hline \multirow[b]{2}{*}{ Indicators } & \multicolumn{5}{|c|}{ The number of insects visiting flowers of 44 species of melliferous plants per $1 \mathrm{~m}^{2}$ within one hour } \\
\hline & Apis mellifera L. & Bumblebees (Bombidae) & $\begin{array}{l}\text { Muscid flies } \\
\text { (Muscidae) }\end{array}$ & $\begin{array}{l}\text { Social wasps } \\
\text { (Vespidae) }\end{array}$ & Other insects \\
\hline & \multicolumn{5}{|c|}{$9.00-10.00$} \\
\hline \multirow[t]{2}{*}{ Lim } & $1.8-27.7$ & $1.3-9.2$ & $2.6-22.7$ & $1.2-11.6$ & $2.9-35.9$ \\
\hline & \multicolumn{5}{|c|}{$12.00-13.00$} \\
\hline$X \pm S_{\bar{X}}$ & $9.40 \pm 0.79$ & $4.40 \pm 0.33$ & $8.60 \pm 0.72$ & $4.50 \pm 0.31$ & $11.20 \pm 0.74$ \\
\hline \multirow[t]{2}{*}{ Lim } & $1.6-30.2$ & $1.0-10.1$ & $2.6-25.7$ & $1.4-11.8$ & $4.8-30.3$ \\
\hline & \multicolumn{5}{|c|}{$17.00-18.00$} \\
\hline$X \pm S_{\bar{X}}$ & $7.60 \pm 0.70$ & $3.60 \pm 0.28$ & $7.80 \pm 0.59$ & $4.20 \pm 0.27$ & $10.40 \pm 0.73$ \\
\hline \multirow[t]{2}{*}{ Lim } & $1.2-23.6$ & $0.9-10.7$ & $2.4-23.4$ & $1.0-8.1$ & $3.2-26.8$ \\
\hline & \multicolumn{5}{|c|}{ Total per day } \\
\hline$X \pm S_{\bar{X}}$ & $8.6 \pm 0.71$ & $4.0 \pm 0.28$ & $8.7 \pm 0.66$ & $4.5 \pm 0.28$ & $11.1 \pm 0.72$ \\
\hline Lim & $1.5-25.4$ & $1.5-9.4$ & $2.7-23.3$ & $1.8-9.9$ & $4.1-31.0$ \\
\hline
\end{tabular}

In the central part, the share of mellifluous bees working on flowers was $23.31 \%$, of bumblebees - $10.84 \%$, of muscid flies $23.58 \%$, of wasps $-12.19 \%$, and of other insects $-30.08 \%$ (Table 2). Other insects included representatives of butterflies (Lepidoptera), beetles (Coleoptera), dipterans (Diptera), and hemipterans (Hemiptera). Lepidopterans were especially numerous they included 144,000 species. It was virtually impossible to identify all of them, since there were too many representatives of other orders [10]; therefore, their nectar-collecting activity was recorded as "other insects".

The observations have established that the number of plant and insect species in the central part of the Vasyugan Plain is greater than that in the eastern part, and depends on the climatic conditions. The central part is considerably warmer than the eastern part. The increased air temperature contributed to increasing the number of plant and insect species.

To determine the biological resources of the Vasyugan Plain, fixed route inspections were performed for counting the number of species of legumes (Leguminosae), cereals (Gramineae), herbs in the Vasyugan Plain that were suitable mainly for industrial-scale bee yards and establishment of meat horse breeding, cattle breeding and other agricultural enterprises.

For assessing the fodder base, forests in the following areas of the Novosibirsk region were studied: Kochenevsky, North, Chulym- sky, Kolyvansky, and partially Kyshtovsky. In addition to the authors, stuff of the department and graduate students participated in the research, and the data obtained by former regional beekeeping specialists where used (Table 3 ).

Table 3: The average amount of produced nectar per 1 hectare of the cut down forest in the Novosibirsk region

\begin{tabular}{|c|c|c|c|}
\hline Lands & Melliferous plants & $\begin{array}{l}\text { \% of } \\
\text { growth }\end{array}$ & $\begin{array}{c}\text { Total } \\
\text { nectar, } \\
\text { kg }\end{array}$ \\
\hline \multirow{5}{*}{ 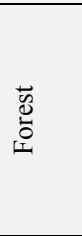 } & $\begin{array}{l}\text { 1. Siberian pea shrub } \\
\text { (Caragana sibirica Lam.) }\end{array}$ & 10 & 35 \\
\hline & $\begin{array}{l}\text { 2. Bush honeysuckle (Lonicera tatarica } \\
\text { L.) }\end{array}$ & 2 & 4 \\
\hline & 3. Red raspberry (Rubus idaeus L.) & 0.5 & 0.75 \\
\hline & 4. Willows of all species (Salix L.) & 15 & 30 \\
\hline & 5. Bird cherry (Prunus padus L.) & 5 & 2 \\
\hline \multirow{5}{*}{ 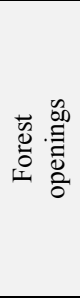 } & $\begin{array}{l}\text { 1. Crowned sawwort } \\
\text { (Serratula coronata } \mathrm{L} .)\end{array}$ & 1 & 4 \\
\hline & $\begin{array}{l}\text { 2. Woodland angelica } \\
\text { (Angelica sylvestris L.) }\end{array}$ & 1.5 & 4,5 \\
\hline & $\begin{array}{l}\text { 3. Rosebay willowherb } \\
\text { (Epilobium angustifolium L.) }\end{array}$ & 5 & 15 \\
\hline & $\begin{array}{l}\text { 4. Melancholy thistle } \\
\text { (Cirsium heterophullum L.) }\end{array}$ & 15 & 15 \\
\hline & 5.Soft lungwort & 3 & 1,8 \\
\hline
\end{tabular}




\begin{tabular}{|l|l|c|c|}
\hline \multirow{5}{*}{} & $\begin{array}{l}\text { (Pulmonaria mollissima A. Kerner) } \\
\text { (Taraxacum officinale L.) }\end{array}$ & 20 & 20 \\
\cline { 2 - 4 } & 7. Cow parsley (Anthriscus sylvestris L.) & 21 & 1 \\
\cline { 2 - 4 } & 8. White clover (Trifolium repens L.) & 1 & 1 \\
\hline Total: & & 134.05 \\
\hline
\end{tabular}

The data in Table 3 show that a hectare of forest located to the north from $50^{\circ} \mathrm{N}$ produces $134.05 \mathrm{~kg}$ of nectar. With this amount of nectar produced on the average by 1 ha, the entire territory of the Vasyugan Plain is suitable for Organic Beekeeping and obtaining Organic Honey.

It has been found that in the environmentally safe area, both high and low cereals grow vigorously: cocksfoot (Dactylis glomerata L.), awnless brome (Bromus inermis Leyss.), smooth meadow grass (Poa pratensis L.), rough meadow grass (Poa trivialis L.); species of genera: slough grass (Beckmannia), ribbon grass (Phalaris), bentgrass (Agrostis), and several others. The range of cereals is complemented by legumes: white sweet clover (Melilotus albus Medik.), sweet clover (Melilotus officinalis L.), alfalfa (Medicago sativa L.), purple milk vetch (Astragalus danicus Retz.), white trefoil (Trifolium repens L.), alsike clover (Trifolium hybridum L.), cow clover (Trifolium pratense L.), bush vetch (Vicia sepium L.), bird vetch (Vicia cracca L.), and craw pea (Lathyrus pratensis L.). The richness of the fodder base is supplemented by edible plants: dissected cow parsnip (Heracleum dissectum Ledeb.), cow parsnip (Heracleum sibiricum L.), wood geranium (Geranium sylvaticum L.); species of genera: hawksbeard (Crepis L.), bennet (Geum L.). Such abundance of meadow vegetation may be efficiently used in meat horse breeding and in meat-and-milk cattle breeding with natural fattening.

\section{Conclusion}

1. The Vasyugan swamp with the area of $5,269,437$ ha is an environmentally pure and safe location. In this territory, men do not plough, sow, or cultivate plants, and the nature itself delivers $134.05 \mathrm{~kg}$ of nectar per hectare every year. If these biological resources are used, our country will come to the first place in the world in the production of Organic Honey, and will take an exclusive place in exporting Organic Honey to the international market. 2. Meat horse breeding and cattle breeding with natural fattening are not a competitor to industrial beekeeping. All three sectors will complement each other, thus contributing to the efficient development of the biological resources in the environmentally safe area of the Vasyugan Plain.

\section{References}

[1] Avetisyan G. A., Gubin A. F. \& Kashkovsky V. G. (1970) Karpatskie pcheli v Sibiri [Carpathian bees in Siberia]. Beekeeping, No. 10, pp. 12-16.

[2] Gubin A. F. (1947) Medonosnie pcheli i opilenie krasnogo klevera [Honeybees and pollination of red clover]. Moscow, Selkhozizdat, $278 \mathrm{p}$.

[3] Gubin A. F. (1948) Pchelovodstvo [Beekeeping]. Moscow, Selkhozgiz, $616 \mathrm{p}$.

[4] Gubin V. A. \& Kashkovsky V. G. (1964) Silnye semyi - eto med! [Strong families are honey!]. Beekeeping, No. 5, pp. 18-20.

[5] Gubin V. A. \& Kashkovsky V. G. (1965) Med ili tsifri? [Honey or numbers?]. Beekeeping, No. 4, pp. 7-9.

[6] Kashkovsky V. G. \& Kiselev N. V. (2010) Vozmozhnosti sozdaniya organicheskogo pchelovodstva v Sibiri [Possibilities of organizing organic beekeeping in Siberia]. Beekeeping, No. 9, pp. 8-9.

[7] Kashkovsky V. G. \& Plakhova A. A. (2010) Rezervi proizvodstva ekologicheski bezopasnoi produktsii pchel [Reserves of obtaining environmentally safe bee products]. Beekeeping, No. 9, pp. 52-53.

[8] Kashkovsky V. G. (1975) Carpathian busy bees in the Kuzbass. Kemerovo, The Kuznetsk Land, pp. 96-100.

[9] Kashkovsky V. G. (1989) Tehnologiya uhoda za pchelami [The technology of caring for the bees]. Novosibirsk: The East-Siberian Book Publishing House, 224 p.
[10] Opredelitel nasekomykh [Manual for the identification of insects] (1933). Leningrad, OGIZ Lenselkhozgiz, 819 p.

[11] Vorozhbitov V. V. (1978) S. I. Gulyaev i pchelovodstvo Sibiri [S. I. Gulyaev and beekeeping Siberia]. Beekeeping, No. 1, pp. 42-43.

[12] Vorozhbitov V. V. (1980) K istorii pchelovodstva Sibiri [To the history of beekeeping in Siberia]. Beekeeping, No. 12, pp. 23.

[13] Yakovlev B. V. (1974) Obschaya entomologiya [General entomology]. Moscow, Vysshaya Shkola, 272 p. 